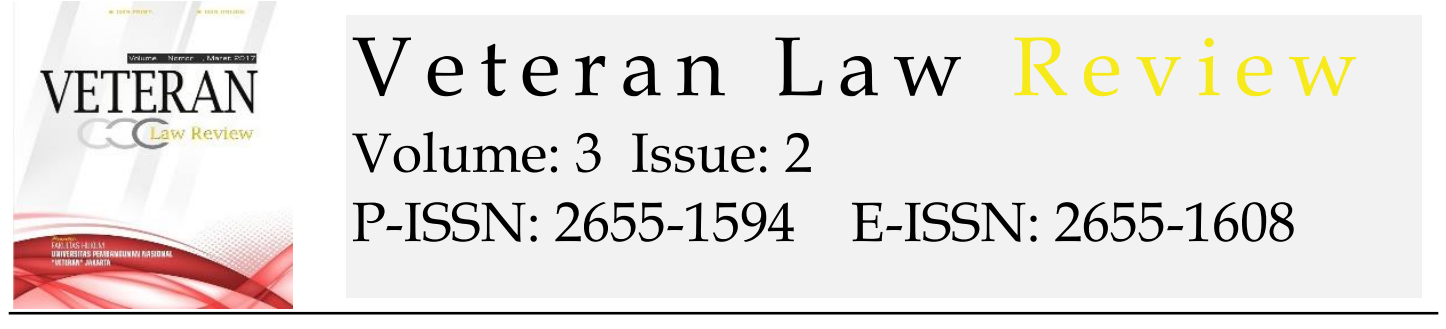

\title{
Legal Impact From Lambe Turah Account Relating To Article Of Insult And Prohibited Conduct
}

\author{
Risa Gia Anjani ${ }^{1}$, Dwi Aryanti Ramadhani², Rianda Dirkareshza ${ }^{3}$ \\ ${ }^{1}$ Faculty of Law, Pembangunan Nasional Veteran University, E-mail: risagiaanjani@upnvj.ac.id \\ ${ }^{2}$ Faculty of Law, Pembangunan Nasional Veteran University, E-mail: dwiaryanti@upnvj.ac.id \\ ${ }^{3}$ Faculty of Law, Pembangunan Nasional Veteran University, E-mail: riandadirkareshza@upnvj.ac.id
}

\begin{tabular}{ll}
\hline \multicolumn{1}{c}{ ARTICLE INFO } & \multicolumn{1}{c}{ ABSTRACT } \\
\hline $\begin{array}{l}\text { Keywords: } \\
\text { Lambe Turah; Spread of } \\
\text { Privacy; Anonymity }\end{array}$ & $\begin{array}{l}\text { Instagram is an information dissemination platform that is very } \\
\text { attractive to Indonesians. The popularity of the Lambe Turah gossip } \\
\text { account on social media Instagram is not necessarily free from the } \\
\text { applicable legal rules, that all social media activities related to insulting } \\
\text { and spreading the privacy of others is a violation that refers to the } \\
\text { Criminal Code and the Law Information and Electronic Transactions. }\end{array}$ \\
$\begin{array}{l}\text { Anjani, R.G., } \\
\text { Ramadhani, D.A. \& }\end{array}$ & $\begin{array}{l}\text { The research method in this scientific work is a normative-juridical } \\
\text { sirkareshza, R. (2020). }\end{array}$ \\
$\begin{array}{l}\text { Legal Impact Of Lambe } \\
\text { Turah Account } \\
\text { Relating To Article Of } \\
\text { Insult And Prohibited } \\
\text { Conduct. Veteran Law } \\
\text { Review. } 3(2) .69-81\end{array}$ & $\begin{array}{l}\text { personal information approach and analyzed qualitatively. Lambe } \\
\text { comments from followers, which can lead to defamation. The anonymity } \\
\text { used by the Lambe Turah admin can be revealed with the help of the } \\
\text { Cyber and Code National Agency or in collaboration with related social } \\
\text { media companies. So that something similar does not happen again, law } \\
\text { enforcement should be able to supervise entertainment accounts on } \\
\text { social media. }\end{array}$ \\
\hline
\end{tabular}

\section{Introduction}

In today's digital and big data era, information is very easy to obtain in various ways. Information is not only obtained through print media and television anymore, but can also be obtained in cyberspace after the presence of the internet. Information via the internet also has various social media platforms in it, which can be in the form of websites and applications. The use of social media is used by the community in carrying out many activities ranging from entertainment, doing business, finding information or other activities ${ }^{1}$. The sooner information is shared, the faster the Indonesian people will have broader insight and knowledge. However, this is not only positive, one of the negative impacts is that there is less space for privacy for the community. This privacy has begun to disappear due to the ease with which people can

Indika, D. R. \& Jovita, C. (2017). Media Sosial Instagram Sebagai Sarana Promosi untuk Meningkatkan Minat Beli Konsumen. In Jurnal Bisnis Terapan. 1(1). 25 
download and access various information, and people can even become independent journalists.

When looking at privacy concerns in the big data domain we need to distinguish which of the many big data application domains we are discussing. Traditional big data applications such as astronomy and e-science usually operate on non-personal information and as they usually do have no significant privacy concerns. Privacy-critical big data applications lie in a new domain of social networking, consumer and business analytics and government surveillance ${ }^{2}$. In this domain big data research is being used to create and analyze specific profiles, for example for market research, targeted advertising, workflow enhancement or national security. This is a very controversial issue since it is entirely dependent on the controller of the big data set if the information obtained is used for malicious purposes or not ${ }^{3}$. Not only big data can be spread widely and misused by irresponsible people, daily activities that are covered by unknown people can also be another legal problem.

One of the platforms for disseminating information that is very popular with Indonesians is Instagram. Instagram is an image-based smartphone application, where users can take and share photos and videos online. Instagram also has a mobile service / application that allows posting images in a Twitter-like manner. The resized image is stripped of metadata but with an optional location the data is stored by the service. In addition, they allow sending photos of various services such as Flickr, Facebook, Dropbox, Foursquare and others. Depending on the services used, metadata is stored or discarded. For example, when uploading photos to Instagram metadata is released from the actual file, but the title, description and geographic location are extracted from the image and can be set by the user.

The Instagram platform is ranked fourth as the most used social media in Indonesia. There are 53 active Instagram users from Indonesia as of 2018 million ${ }^{5}$. The main feature on the Instagram platform is that users can follow other user accounts. Various photos and videos uploaded by this account will later become the contents of the homepage on Instagram that is used. One of the most popular accounts for Instagram users in Indonesia is the gossip account, until now the most popular account is called Lambe Turah. The speed and noise of Lambe Turah's gossip has transformed the market and the gossip business, which was once the dominant toy of the television and tabloid

\footnotetext{
Bond, D, K. Crawford. (2011). Six Provocations for Big Data (pp. 11). SSRN eLibrary. Matthew, Smith, Szonggot \& Voigt. V. (2012). Big Data Privacy Issues in Public Social Media (pp. 1). IEEE International Conference on Digital Ecosystems and Technologies.

4 Gedik, B, Liu, L. (2008). Protecting Location Privacy with Personalized Anonymity: Architecture and Algorithms. In IEEE Transactions on Mobile Computing. 7 (1). 5.

5 Jayani, Dwi Hadya. (2020, February 26). 10 Media Sosial yang Paling Sering Digunakan Di Indonesia [Databoks]. Retrieved from https://databoks.katadata.co.id/datapublish/2020/02/26/10-media-sosial-yangpaling-sering-digunakan-di-indonesia
} 
industry ${ }^{6}$. This happened because Lambe Turah was considered to be quicker to provide the latest gossip material compared to television and tabloid gossip programs.

In a fairly short time, Lambe Turah has transformed into a new journalist in the focus of reporting on Indonesian public figures. Lambe Turah always provides the latest news and provides information faster than other competitors, both gossip accounts on other Instagram and television and tabloids, even though the news presented by Lambe Turah does not pay attention to journalistic ethics in accordance with UU No. 40 of 1999 concerning the Press and protection of personal data of a person intentionally and without the right to be distributed, transmitted and made accessible to information and electronic documents that contain defamation and / or defamation in accordance with UU No. 11 of 2008 in conjunction with UU No. 19 of 2016 concerning Electronic Information and Transactions. Some of the posts from the Lambe Turah account are considered very informative for a number of circles, but not a few also feel that the posts uploaded by the account are considered detrimental to public figures who have been exposed without approval.

On the other hand, in the use of communication media, users must follow all applicable legal rules. This is done so that there is no misuse of the media as a means of communication by irresponsible persons. Likewise for Instagram users. The popularity of Lambe Turah's gossip account is not necessarily free from the applicable law in the use of communication media. As an entertainment account, Lambe Turah should be subject to the Information and Electronic Transactions Law and the Criminal Code relating to the privacy of other people. Based on the background above, the problems that arise are:

1) What form of insult did the Lambe Turah gossip account have?

2) What are the forms of violations committed by the Lambe Turah gossip account?

3) What is the legal impact of Lambe Turah's gossip account on social media regarding the article of insults and UU No. 11 of 2008 in conjunction with Law No. 19 of 2016 concerning Electronic Information and Transactions?

\section{Method}

The research method is basically a series of stepwise procedures or systematic methods used to find the truth in a scientific work, in this case journal writing, so that it can produce a quality journal, namely journals that meet the research requirements ${ }^{7}$. The type of research in this journal is literary or library research (library research), which means a study by examining books or books related to this journal that comes from the library (library material). All sources come from written materials (print) related to research problems and other literature

6 Putri, Restu Diantina. (2018, Desember 10). Di Balik Cara Kerja Lambe Turah dan Akun Gosip Lain [Tirto]. Retrieved from https:/ / tirto.id/di-balik-cara-kerja-lambe-turah-danakun-gosip-lain-dbqh

7 Soemitro. (1990). Metodologi Penelitian Hukum. Jakarta: Rineka Cipta. 
(electronic) ${ }^{8}$. The approach in research is divided into two, namely a qualitative approach and a quantitative approach. In writing this journal, the approach used is a qualitative approach, that is, an approach in processing and analyzing data does not use numbers, symbols and / or mathematical variables but with in-depth analysis. In the discussion, the researcher uses a juridical-normative approach, which is a type of approach that uses statutory provisions in force in a country or a doctrinal legal approach method, namely legal theories and opinions of legal scientists, especially those related to the issues discussed ${ }^{9}$. The juridical-normative approach used in this study is the approach through positive law, namely examining positive legal rules to examine the legal impact that Lambe Turah's gossip account should have. The materials that are the object of research are books and laws on Civil Law and the Criminal Code. This journal writing is based on primary research material sources and secondary research material sources, namely ${ }^{10}$ :

1) Primary Legal Materials, namely binding legal materials ${ }^{11}$ such as the 1945 Constitution; Code of Civil law; Book of Law No. 11 of 2008 in conjunction with Law No. 19 of 2016 concerning Electronic Transaction Information.

2) Secondary legal materials that provide an explanation of primary legal materials, such as academic papers, draft laws, research results, or opinions of legal experts.

3) Third, tertiary legal materials that provide guidance and explanation for primary and secondary legal materials such as dictionaries and encyclopedias. ${ }^{12}$

\section{Main Heading of the Analysis or Results}

\subsection{The form of insults committed by the gossip account Lambe Turah}

Lambe Turah is a gossip account that was formed in December 2015, this account has a number of followers of 7.6 million Instagram users. Lambe turah generally uploads images or videos with low quality and provides a watermark to make it appear that the news is his. Not only limited to cyberspace, but currently Lambe Turah also has an influence on national television, even being the most up to date and reliable source of information. Information obtained by the Lambe Turah account is usually obtained from someone who sends a photo or video proof through the DM (Direct Message) feature of Instagram to the Lambe Turah account ${ }^{13}$. The content shared by Lambe Turah varies, from the latest phenomena to news about celebrity privacy or often called gossip. The gossip shared by Lambe Turah often raises

\footnotetext{
8 Hadi, Sutrisno. (1980). Metodologi Research 1. Yogyakarta: Gajah Mada.

9 Soemitro. (1998). Metodologi Penelitian Hukum dan Jurimetri. Jakarta: Ghalia Indonesia.

10 Arikunto, Suharsimi. (2000). Prosedur Penelitian suatu Pendekatan Praktek. Jakarta: Rineka Cipta.

11 Soekanto, Soerjono. (1984). Pengantar Penelitian Hukum. Jakarta: UI-Press.

12 Amiruddin, Asikin, Zainal. (2006). Pengantar Metode Penelitian Hukum. Jakarta: PT. Raja Grafindo.

13 Rakhmawati, Nur Aini, et al. (2019). Konsep Perlindungan Hukum Atas Kasus Pelanggaran Privasi Dengan Pendekatan Perundang-undangan dan Pendekatan Konseptual. In Justitia Jurnal Hukum. 3(2). 297-304
} 
various speculations from his followers, thus drawing accusing comments that tend to be negative towards the celebrity. Yet as is well known, that gossip is not necessarily something that actually happened.

Lambe Turah's content that often causes controversy is the "Hengpon Jadul" segment. The content contains photos or video footage of someone taken secretly without his knowledge, this action can also be called paparazzi. When uploaded to Instagram social media, the content is written in a sentence that contains a clue or a clue about the name of a celebrity or the activities it carries out. It cannot be denied that it is very likely that the Lambe Turah admin did not apply for permission to the person concerned when he wanted to upload content regarding "Hengpon Jadul" photos and videos. Even though the person concerned may not necessarily be pleased if the content is published, especially it is related to their privacy.

Table 1. Content Description "Hengpon Jadul" Lambe Turah

\begin{tabular}{|c|c|c|c|}
\hline No. & Content & Information & Article being violated \\
\hline \multirow[t]{3}{*}{1.} & Date & March 10, 2020 & \multirow{3}{*}{$\begin{array}{l}\text { Article } 310 \text { of the } \\
\text { Criminal Code } \\
\text { Article } 315 \text { of the } \\
\text { Criminal Code } \\
\text { Article } 26 \text { of the UU } \\
\text { ITE } \\
\text { Article } 27 \text { paragraph } 3 \\
\text { of the UU ITE } \\
\text { Article } 45 \text { paragraph } 3 \\
\text { of the UU ITE }\end{array}$} \\
\hline & $\begin{array}{l}\text { Public } \\
\text { figure }\end{array}$ & Gracia Indri & \\
\hline & Description & $\begin{array}{l}\text { A photo showing Gracia Indri with a } \\
\text { boy on vacation. The photo is } \\
\text { accompanied by the caption: "With } \\
\text { power of hengpon jadul. Cekrek- } \\
\text { cekrek upload. Duhhh, hengpon jadul } \\
\text { is on vacation and accidentally meets } \\
\text { someone who is on holiday too." The } \\
\text { photo gets 165,840 likes and } 3,840 \\
\text { comments, There are a few comment } \\
\text { body shaming, including: "Yes, she is } \\
\text { Gracia, that's her sunglasses and look } \\
\text { at her big calves"; "So fat"; "The } \\
\text { calves are very big" }\end{array}$ & \\
\hline \multirow[t]{3}{*}{2.} & Date & August 25, 2019 & \multirow{3}{*}{$\begin{array}{c}\text { Article } 310 \text { of the } \\
\text { Criminal Code } \\
\text { Article } 315 \text { of the } \\
\text { Criminal Code } \\
\text { Article } 26 \text { of the UU } \\
\text { ITE } \\
\text { Article } 27 \text { paragraph } 3\end{array}$} \\
\hline & $\begin{array}{l}\text { Public } \\
\text { figure }\end{array}$ & Arifin Putra & \\
\hline & Description & $\begin{array}{l}\text { A photo showing Arifin Putra with a } \\
\text { woman on an MRT train. The photo } \\
\text { is accompanied by a caption: } \\
\text { " } U g h h h \text {, hengpon jadul meets Arifin } \\
\text { Putra the handsome man. Minceu }\end{array}$ & \\
\hline
\end{tabular}




\begin{tabular}{|c|c|c|c|}
\hline & & $\begin{array}{l}\text { very curious". The photo received } \\
168,275 \text { likes and } 4,756 \text { comments. } \\
\text { There are several comments on body } \\
\text { shaming, including: "Her butt is } \\
\text { really down. Please wear a corset } \\
\text { please"; "Thighs full of cellulite. } \\
\text { Why does she really want to show } \\
\text { off"; "Hadehh, the girl's clothes are } \\
\text { ugly and her feets are charred" }\end{array}$ & $\begin{array}{c}\text { of the UU ITE } \\
\text { Article } 45 \text { paragraph } 3 \\
\text { of the UU ITE }\end{array}$ \\
\hline \multirow[t]{3}{*}{3.} & Date & July 11, 2019 & \multirow{3}{*}{$\begin{array}{l}\text { Article } 310 \text { of the } \\
\text { Criminal Code } \\
\text { Article } 315 \text { of the } \\
\text { Criminal Code } \\
\text { Article } 26 \text { of the UU } \\
\text { ITE } \\
\text { Article } 27 \text { paragraph } 3 \\
\text { of the UU ITE } \\
\text { Article } 45 \text { paragraph } 3 \\
\text { of the UU ITE }\end{array}$} \\
\hline & $\begin{array}{l}\text { Public } \\
\text { figure }\end{array}$ & Kriss Hatta & \\
\hline & Description & $\begin{array}{l}\text { A photo showing Kriss Hatta with a } \\
\text { woman in a lounge. The photo is } \\
\text { accompanied by a caption: "Ughhh, I } \\
\text { forgot to upload this photo. Yesterday } \\
\text { hengpon jadul met a handsome man. } \\
\text { Seriously, you are getting more } \\
\text { cool". The photo received } 89,542 \\
\text { likes and } 1,659 \text { comments. There are } \\
\text { several comments on hate speech and } \\
\text { body shaming, including: "She is old, } \\
\text { I can see her paunch", "Aunt's thirst } \\
\text { flared up" }\end{array}$ & \\
\hline
\end{tabular}

Source: Lambe Turah Instagram Account, 2019-2020

Privacy is a person's right that must be protected so that their personal life is not disturbed. Privacy is an important aspect of increasing data publication. Meanwhile, personal privacy is a condition when things that belong to others cannot be accessed so that the information is not accessible to other people's senses or surveillance devices ${ }^{14}$. Thus, it is very important to understand about technological developments and how they affect the privacy and security rights of social media users ${ }^{15}$.

The feedback from photo uploads in the form of comments from netizens often creates dislike for both the artist being talked about and the artist's followers or fans. Not infrequently there is a war of comments on Lambe Turah's Instagram account. Based on these conditions, uploading the Lambe Turah account often triggers hate speech from the account's followers. Dislike of what is uploaded is written directly in the comments column that can be read by others. The way of delivery sometimes does not pay attention to politeness in language and empathy for objects that are the subject of conversation on

\footnotetext{
$14 \quad$ Ibid, (pp. 298).

15 Isaak, Jim. (2018). User Data Privacy: Facebook, Cambridge Analytica, and Privacy Protection. The Policy Corner.
} 
Instagram. The language used in comments and photo status uploaded on Instagram leads to expressions or speech of hatred so that it can provoke or cause emotions, displeasure in others ${ }^{16}$. Comments that tend to be negative on the content can also cause defamation of the person concerned.

\subsection{Forms of violations committed by the Lambe Turah gossip account}

Social media is a virtual representation of a person, which reveals that person's personal and work information. Under certain circumstances, demands for information have prompted irresponsible parties to use a variety of methods to illegally break into sensitive information or someone's privacy. In fact, privacy is a top priority when sharing information via social media ${ }^{17}$. One form of violation that was committed and uploaded by the Lambe Turah gossip account was the content of "Hengpon Jadul". The content is an act of spreading personal information and defamation. Based on this action, it is appropriate for the Lambe Turah account admin or the person responsible for the content to be charged with the articles listed in the Criminal Code and the Information and Electronic Transaction Law, which are as follows:

\section{Article 310 of the Criminal Code ${ }^{18}$}

(1) "Anyone who deliberately attacks honor or reputation A person accusing him of something, which means clearly so that it is made public, is threatened with defamation by a maximum imprisonment of nine months or a maximum fine of four thousand and five hundred rupiahs.

(2) If this is done in writing or an illustration broadcast, shown or posted in public, then he will be punished for defamation with a maximum imprisonment of one year and four months or a maximum fine of four thousand and five hundred rupiahs."

\section{Article 315 of the Criminal Code}

"Every deliberate insult, which is not defamatory or defamatory in writing, committed against a person, either in public orally or in writing, or in the face of that person by mouth or deed, or by letter sent or received to him, is threatened with light humiliation with a maximum imprisonment of four months and two weeks, or a maximum fine of Rp 4,500."

The two articles above are listed in the Criminal Code, which every community is obliged to obey as public law for public order and security. However, none of the admin or the person responsible for the content distributed by the Lambe

16 E. Y., Margaretha, Nugrahaningsih, Widi. (2017). Ujaran Kebencian Dalam Komentar Akun Instagram. In Seminar Nasional Teknologi Informasi dan Bisnis.

17 I.I., Mohd, et al. (2016). Exploiting Privacy Policy and Management Features on Social Networks: A User's Perspective. In International Conference on Computer \& Communication Engineering. Indonesia, Criminal Code, Articles 310 and 315. 
Turah Account is entangled in the article that has been described. Likes and comments have been widely used as a measure for the impact of a publication $^{19}$. The Lambe Turah account has a large number of followers so that it has a big impact on the dissemination of information. In this regard, the "Hengpon Jadul" content created by the account cannot be confirmed, especially if the content created and distributed unilaterally has become a violation of the Criminal Code.

\section{Article 26 of the UU ITE ${ }^{20}$}

(1) "Unless otherwise stipulated by laws and regulations, The use of any information through electronic media that involves a person's personal data must be done with the consent of the person concerned.

(2) Any person whose rights have been violated as referred to in the paragraph (1) may file a lawsuit for damages incurred under this Law."

\section{Article 27 paragraph 3 of the UU ITE}

"Anyone who knowingly and without right distributes and/or transmits and/or makes accessible information and/or electronic documents that are in possession of defamatory and/or defamatory contents"

Defamation based on the Information and Electronic Transactions Law (UU ITE) is a law that discusses legal provisions regarding problems that occur in the field of information and communication technology developments that arise in society. Defamation committed by the Lambe Turah account can also cause hate speech. Hate speech is an unethical attitude, does not show nationalist values and intolerance that can lead to violence (condoning). If hate speech is not taken seriously, then this kind of attitude will be a bad asset for strengthening democracy and human rights ${ }^{21}$. Hate speech is one of the electronic transaction activities because it is carried out through electronic media. The ITE Law defines electronic transactions as "legal acts carried out using computers, computer networks, and/or other electronic media".

The ITE Law states that violations of acts prohibited under Article 26 and 27 paragraph (3) are a form of prohibition in spreading privacy to other people. The ITE Law regulates criminal sanctions for these prohibited acts in accordance with each of these articles. Changes in criminal sanctions are contained in UU No. 19 of 2016 as an amendment to UU No. 11 of 2008.

19 Santoso, Amanda P., et al. (2017). Pengaruh Konten Post Instagram terhadap Online Engagement:Studi Kasus Pada Lima Merek Pakaian Wanita. In Jurnal Sains dan Seni ITS. 6(1). 51.

20 Indonesia, UU No. 11 of 2008 about Electronic Information and Transactions, Articles 26 and 27 paragraph 3.

21 Irawan. (2018). Hate Speech di Indonesia: Bahaya dan Solusi. In Jurnal Dakwah dan Pengembangan Sosial Kemanusiaan. 9(1). 5. 
Criminal sanctions for Article 27 paragraph (3) are contained in Article 45 paragraph (3) as follows ${ }^{22}$ :

(3) "Anyone who knowingly and without right distributes and/or transmits and/or makes accessible Electronic Information and/or Electronic Documents that contain insults and/or defamation as referred to in Article 27 paragraph (3) shall be sentenced to imprisonment. a maximum of 4 (four) years and/or a fine of not more than IDR 750,000,000.00 (seven hundred and fifty million rupiah).

This article clearly shows that the spread of other people's privacy in any form that can harm other people is subject to imprisonment and/or a fine in accordance with the applicable provisions above. Social media users are looking for information that will have an impact in various ways ${ }^{23}$. However, with the rapid advancement of technology, the dissemination of information not only has a positive impact, it can also have a significant negative impact. Public figures who are very easily highlighted by the mass media are also very vulnerable to their personal lives being publicized in general and are very easily to be abused by the public, one of the concrete forms is content created by gossip accounts discussed in this scientific paper.

3.3. The legal impact of Lambe Turah's gossip account on social media in relation to articles of insult and UU No. 11 of 2008 in conjunction with UU No. 19 of 2016 about Electronic Transaction Information

In 2010, Mark Zuckerberg, commenting on the rise of social networking sites, said that social media users are becoming more comfortable sharing their personal information or privacy online or online ${ }^{24}$. There are two main types of attacks on online social networks. First, it is done by exploiting security holes in the network and the second is done by abusing the trust between users. The second type is sometimes easier to do, because social media users are not always cautious ${ }^{25}$. The visibility provided by social media provides its own enigma: it can provide social support, attention, and even popularity, but at the same time leave people open to criticism, drama and conflict ${ }^{26}$. Privacy can be defined as the right to determine for themselves which information can be accessed by whom and when or as " selective access control over oneself ". The level of privacy aimed covers various aspects, one of which is from a

22 Indonesia, UU No. 19 of 2016 about Amendments to UU No. 11 of 2008 about Electronic Information and Transactions, Article 45 paragraph 3.

23 Lipschultz, Jeremy Harris. (2017). Social Media Communication: Concepts, Practices, Data, Law and Ethics. New York: Routledge.

24 Sarikakis, Katharin E Winter, Lisa. (2017). Social Media Users' Legal Consciousness About Privacy. In Social Media + Society. (pp. 1-2)

25 Wong, Kaze, et al. (2014). Trust and Privacy Exploitation in Online Social Networks. In Consumerization of It. (pp. 28).

26 Marwick, Alice, et al. (2017). Nobody Sees It, Nobody Gets Mad: Social Media, Privacy, and Personal Responsibility Among Low-SES Youth. In Social Media + Society. (pp. 1). 
psychological point of view which must be understood as protection against external influences on personal thoughts and attitudes ${ }^{27}$.

There are some people who still seek the privacy of others to share without the permission of the parties concerned with the aim of getting personal benefits, such as the content of "Hengpon Jadul" belonging to the Lambe Turah account which has been reviewed in this scientific paper. Some public figures have become victims of these content objects, mistakes or disgrace by public figures that have been sold for public consumption by the Lambe Turah account. Even the existence of the content "Hengpon Jadul" has an impact on the number of followers and the existence of the Lambe Turah account which is increasing over time. As is well known, the actions taken by the Lambe Turah admin were against the law.

One of the reasons the Lambe Turah admin is not caught in a legal case is anonymity. Anonymity comes from a Greek word meaning 'without a name' which is used to identify objects whether they are humans or objects ${ }^{28}$. The identity of the Lambe Turah admin is not clearly known. In their account activity, the admin is only often called by the name "Minceu". However, if anonymity is used as the main reason by law enforcers for avoiding the Lambe Turah admin from being caught in a legal case, then this can be denied. In social media youtube, Erdian Aji Prihartanto (more popular with the name Anji or Manji) has managed to meet and chat with one of Lambe Turah's admins, their conversations have been uploaded publicly on Anji's YouTube account. This indicates that Lambe Turah is not an account controlled by a bot $^{29}$, but fully controlled by humans, who are legal subjects.

On the other hand, law enforcers can also cooperate with the National Cyber and Crypto Agency to reveal the identity of the owner or admin of Lambe Turah. Law enforcement can manually search accounts or use search engines to index social media data, if the information is publicly available. They can also request information from social media companies that is not available to the general public. Law enforcement can choose to get a court order to find out someone's social media account activity. This technique is similar to wiretapping and uses software installation to gather information about the person concerned. Finally, law enforcement can collect data from multiple social media accounts and perform additional qualitative or quantitative analysis of that information ${ }^{30}$.

\section{Conclusion}

27 Taddicken, Monika. (2014). The 'Privacy Paradox' in the Social Web: The Impact of Privacy Concerns, Individual Characteristics, and the Perceived Social Relevance on Different Forms of Self-Disclosure. In Journal of Computer-Mediated Communication. (pp. 249).

28 Hasfi, Nurul, et al. (2017). Anonimitas di Media Sosial: Sarana Kebebasan Berekspresi atau Patologi Demokrasi?. In Jurnal Ilmu Komunikasi. 15(1). (pp. 28).

29 Bot is a computer program that can do jobs automatically.

30 Rice, Stephen K \& Parkin, William S. (2016). Social Media and Law Enforcement Investigations. Oxford: Oxford University Press. 
The content belonging to the Lambe Turah account entitled "Hengpon Jadul" can be said to be an act of insult. The content contains photos or video footage of someone taken secretly without the knowledge of the person concerned. So, it can be seen that the content is related to the privacy of other people. Most likely, the admin of Lambe Turah or often called "Minceu" did not apply for permission to the person concerned when he wanted to upload content regarding the photos and videos.

The spread of privacy carried out and uploaded by the Lambe Turah gossip account can lead to various speculations that can lead to gossip. The followers of the Lambe Turah account are often incited to give negative comments that result in hate speech and defamation against the person concerned or the celebrity. Based on this, the Lambe Turah admin has violated the law and can be charged under Article 310 of the Criminal Code, Article 315 of the Criminal Code, Article 26 of the ITE Law, Article 27 paragraph 3 of the ITE Law and Article 45 paragraph 3 of the ITE Law.

Until now, the admin or the person responsible for the Lambe Turah account's "Hengpon Jadul" content has never been caught in a legal case. One of the reasons Lambe Turah was not caught in a legal case, namely because of the anonymity used by the admin. However, the fact is that Erdian Aji Prihartanto has met and talked on his Youtube account with the Lambe Turah admin, so it can be seen that the Lambe Turah admin is a real person. In revealing the identity of the Lambe Turah admin, law enforcers can work with the National Cyber and Crypto Agency and social media companies to obtain data or identity belonging to the admin.

Each country has its own legal rules. As is well known, every citizen must comply with the applicable legal rules. Law enforcers should not be impartial in taking firm action against a violation that occurs. Regarding violations committed by someone without identity or anonymity, this is not an obstacle to knowing his true identity. Given, the existence of the National Cyber and Crypto Agency can help efforts to reveal the identity of an anonymity account or it can also work with related social media companies. Meanwhile, law enforcers should be able to supervise entertainment accounts on social media, so that similar things do not happen continuously.

\section{References}

\section{Books}

Asikin, Zainal \& Amiruddin. (2006). Pengantar Metode Penelitian Hukum. Jakarta: PT. Raja Grafindo.

Arikunto, Suharsimi. (2000). Prosedur Penelitian Suatu Pendekatan Praktek. Jakarta: Rineka Cipta.

Hadi, Sutrisno. (1980). Metodologi Research 1. Yogyakarta: Gajah Mada.

Lipschultz, Jeremy Harris. (2017). Social Media Communication: Concepts, Practices, Data, Law and Ethics. New York: Routledge.

Soekanto, Soerjono. (2015). Pengantar Penelitian Hukum. Jakarta: UI-Press.

Soemitro. (1990). Metodologi Penelitian Hukum. Jakarta: Rineka Cipta. 
Soemitro. (1998). Metodologi Penelitian Hukum dan Jurimetri. Jakarta: Ghalia Indonesia.

Rice, Stephen K \& Parkin, William S. (2016). Social Media and Law Enforcement Investigations. Oxford: Oxford University Press.

\section{Journal Articles}

Brown, Brian A. (2013). Primitive Digital Accumulation: Privacy, Social Network, and Biopolitical Exploitation. Rethinking Marxism. 25(3).

Chirita, Anca D. (2018). The Rise of Big Data and the Loss of Privacy. Springer Nature.

Bond, D \& Crawford, K. (2011). Six Provocations for Big Data. SSRN eLibrary. Gedik, B. \& Liu, L. (2008). Protecting Location Privacy with Personalized Anonymity: Architecture and Algorithms. IEEE Transactions on Mobile Computing. 7(1). 5.

Hasfi, Nurul, Usmand, Sunyoto \& Santosa, Hedi Pudjo. (2017). Anonimitas di Media Sosial: Sarana Kebebasan Berekspresi atau Patologi Demokrasi?. Jurnal Ilmu Komunikasi. 15 (1). 28.

Indika, Deru R \& Jovita, Cindy. (2017). Media Sosial Instagram Sebagai Sarana Promosi untuk Meningkatkan Minat Beli Konsumen. Jurnal Bisnis Terapan. 1(1). 25.

Irawan. (2018). Hate Speech di Indonesia: Bahaya dan Solusi. Jurnal Dakwah dan Pengembangan Sosial Kemanusiaan. 9(1). 5.

Ismail, Mohd Ishak., Rahman, Md Arafatur \& Azad, Saiful. (2016). Exploiting Privacy Policy and Management Features on Social Networks: A User's Perspective. International Conference on Computer \& Communication Engineering. 66.

Markell, Patchen. (2015). Anonymous Glory. European Journal of Political Theory.

Marwick, Alice., Fontaine, Claire \& Boyd, Danah. (2017). 'Nobody Sees It, Nobody Gets Mad': Social Media, Privacy, and Personal Responsibility Among Low-SES Youth. Social Media + Society. 1.

Rakhmawati, Nur Aini, et al. (2019). Konsep Perlindungan Hukum Atas Kasus Pelanggaran Privasi Dengan Pendekatan Perundang-undangan dan Pendekatan Konseptual. Justitia Jurnal Hukum. 3(2). 299.

Santoso, Amanda P., Baihaqi, Imam \& Persada, Satria F. (2017). Pengaruh Konten Post Instagram terhadap Online Engagement: Studi Kasus Pada Lima Merek Pakaian Wanita, Jurnal Sains dan Seni ITS. 6(1). D-51.

Sarikakis, Katharine \& Winter, Lisa. (2017). Social Media Users' Legal Consciousness About Privacy, Social Media + Society. 1-2.

Smith, Matthew., Szonggot, \& Voigt, Von. (2012). Big Data Privacy Issues in Public Social Media. IEEE International Conference on Digital Ecosystems and Technologies. 1.

Sorell, Tom. (2015). Human Rights and Hacktivism: The Cases of Wikileaks and Anonymous. Journal of Human Rights Practice. 7(3).

Sutantohadi, Alief \& Wakhidah, Rokhimatul. (2017) “Bahaya Berita Hoax Dan Ujaran Kebencian Pada Media Sosial Terhadap Toleransi Bermasyarakat". Jurnal Pengabdian Kepada Masyarakat. 1(1). 
Taddicken, Monika. (2014). The 'Privacy Paradox' in the Social Web: The Impact of Privacy Concerns, Individual Characteristics, and the Perceived Social Relevance on Different Forms of Self-Disclosure. Journal of Computer-Mediated Communication. 249.

Yuliana, Margaretha Evi \& Nugrahaningsih, Widi. (2017). Ujaran Kebencian Dalam Komentar Akun Instagram. Seminar Nasional Teknologi Informasi dan Bisnis. 276.

Website

Jayani, Dwi Hadya. (2020). 10 Media Sosial yang Paling Sering Digunakan Di Indonesia (Databoks). Retrieved March 13, 2020 from https:// databoks.katadata.co.id/datapublish/2020/02/26/10-mediasosial-yang-paling-sering-digunakan-di-indonesia

Putri, Restu Diantina. (2010). Di Balik Cara Kerja Lambe Turah dan Akun Gosip Lain (Titro). Retrieved March 11, 2020 from https://tirto.id/dibalik-cara-kerja-lambe-turah-dan-akun-gosip-lain-dbqh

\section{Magazine Articles}

Isaak, Jim \& Hanna, Mina J. (2018, Agustus). User Data Privacy: Facebook, Cambridge Analytica, and Privacy Protection. The Policy Corner.

Wong, Kaze., et. al. (2014, September/October). Trust and Privacy Exploitation in Online Social Networks. Consumerization of It.

\section{Law \& Regulation}

Indonesia, Kitab Undang-Undang Hukum Pidana.

Indonesia, Undang-Undang Nomor 11 Tahun 2008 Tentang Informasi dan Transaksi Elektronik.

Indonesia, Undang-Undang Nomor 19 Tahun 2016 Tentang Perubahan Atas Undang-Undang Nomor 11 Tahun 2008 Tentang Informasi dan Transaksi Elektronik. 